\title{
New dibenzocyclooctadiene lignan from Schisandra chinensis (Turcz.) Baill. fruits
}

\author{
Trong Nguyen Nguyen ${ }^{1 \dagger}$, Yeong-Geun Lee ${ }^{1 \dagger}$, Hyoung-Geun Kim', Dahye Yoon ${ }^{2}$, Jin Tae Jeong ${ }^{2}$, \\ Dae Young Lee ${ }^{2}$ and Nam-In Baek ${ }^{*}$
}

\begin{abstract}
Repeated column chromatography using Sephadex $\mathrm{LH}-20$, silica gel $\left(\mathrm{SiO}_{2}\right)$, and octadecyl $\mathrm{SiO}_{2}(\mathrm{ODS})$ as well as preparative HPLC column chromatography led to isolation of a new dibenzocyclooctadiene lignan along with four known ones, gomisin L2 (1), L1 (2), M1 (3), and M2 (4). Their chemical structures were fixed based on MS, IR, and NMR data analyses. In addition, the stereochemistry of atropisomers, the absolute configuration of the axial chirality in a biphenyl structure, was confirmed by a CD experiment. The new lignan was named gomisin M3 (5).
\end{abstract}

Keywords: Atropisomer, Axial chirality, Circular dichroism, Dibenzocyclooctadiene lignan, Gomisin M3, Schisandra chinensis

\section{Introduction}

Schisandra chinensis (Turcz.) Baill. is a deciduous vine wood originated from eastern Asia and is distributed in Korea, China, and Japan [1]. The fruits have been utilized for thousands years as a superior drug for therapy of persistent dyspnoea and cough, frequent urination, severe sweating, shortness of breath, hepatitis, diabetes, and wasting-thirsting disease [2]. In addition, the extracts or metabolites from the plant were reported to have various biological efficacies such as anti-tussive, astringent, tonics [3], antioxidant [4], anti-inflammatory [5], anti-aging [6], anti-tumor [7], and inhibition of platelet aggregation [8] effects. The fruit of S. chinensis contains lignans, organic acids, monoterpenes, sesquiterpenes, and triterpenoids as major constituents [9]. It has been reported that the pharmacological functions are mostly attributed to lignans, especially the dibenzocyclooctadiene-type lignans [10]. The lignan content of Schisandra fruit has been reported to be high, varying between 7.2 and $19.2 \%$

\footnotetext{
*Correspondence: nibaek@khu.ac.kr

†Trong Nguyen Nguyen and Yeong-Geun Lee made equal contributions to this work (co-first author)

${ }^{1}$ Graduate School of Biotechnology, KyungHee University, Yongin 17104, Republic of Korea

Full list of author information is available at the end of the article
}

$[11,12]$. Lignans are typical component compounds of the Schisandra genus plants; among them, the dibenzocyclooctadiene type is the most popular. Upwards of 150 dibenzocyclooctadiene lignans have been reported from Schisandraceae plants [13]. Dibenzocyclooctadiene lignans are categorized further into two series based on stereostructure, $S$ - and $R$-biphenyl configuration, because they have biaryl bonds at C-6 and C- 6 , and the biphenyl chromophore has no rotational freedom. Therefore, dibenzocyclooctadiene lignans occurred in nature exhibit $S$ and $R$ configurations because of a chiral biphenyl axis in the structure, resulting to atropisomerism, which is derived from rotation hindrance of single bond. The steric repression barrier to rotation is high enough to permit isolation of the conformers, atropisomers. Enantiomeric compounds can behave differently based on pharmacokinetic setting [14]. One study reported that $8 S, 8^{\prime} R$-schisandrin B more potently enhanced cellular glutathione and protection against oxidative injury compared to other diastereomers [15]. In this study, the authors isolated a new dibenzocyclooctadiene-type lignan along with four known ones from the Schisandra chinensis fruits and determined the chemical structure, including absolute configuration of the atropisomers, 
through several spectroscopic analyses including a circular dichroism (CD) experiment.

\section{Materials and methods}

\section{General experimental procedures}

The materials and instruments used in this study were same as previously used ones [16]. And ECD spectra were obtained by Jasco spectropolarimeter J-715, Scan range $200-400 \mathrm{~nm}$, cell length $0.1 \mathrm{~cm}$.

\section{Plant materials}

The Department of Herbal Crop Research, RDA, Eumseong, Korea, supplied S. chinensis fruits in 2019, as verified by Dr. Jin Tae Jeong, Department of Herbal Crop Research, RDA. A guaranteed sample (KHUNPCL-1935) is saved in NPCL Laboratory, KyungHee University, Korea.

\section{Extraction and isolation}

S. chinensis fruits $(5.4 \mathrm{~kg}$, dry weight) were immersed in $70 \%$ ethanol (EtOH, $54 \mathrm{~L} \times 3$ ) at $24{ }^{\circ} \mathrm{C}$ for one day, followed by filtration and vacuum concentration to yield a brownish residue $(1.3 \mathrm{~kg})$. The concentrates were solvent-fractionated using $\mathrm{H}_{2} \mathrm{O}(4.2 \mathrm{~L})$, EtOAc $(4.2 \mathrm{~L} \times 3)$, and $n-\mathrm{BuOH}(3.4 \mathrm{~L} \times 3)$ to give the $\mathrm{H}_{2} \mathrm{O}(\mathrm{SCW}, 723 \mathrm{~g})$, EtOAc (SCE, $329 \mathrm{~g}$ ), and $n$-BuOH (SCB, $247 \mathrm{~g}$ ) fractions. The column chromatography (CC) for SCE (300 g) was carried out using $\mathrm{SiO}_{2}$ resin (Fig. 1). The eluate was analyzed through a TLC experiment to yield 12 fractions (SCE-1 - SCE-12). Open CC of fractions 5 (SCE-5) and 7 (SCE-7) using Sephadex LH-20, ODS, and $\mathrm{SiO}_{2}$ as well as prep-LC using an ODS column (Fig. 1) provided purified lignans, compounds 1-5.

Gomisin L2 (1): white powder; TLC $\left(\mathrm{SiO}_{2}\right) R f$ 0.38, $\mathrm{CHCl}_{3}$-EtOAc (10:1), (ODS) $R f 0.45$, acetone- $\mathrm{H}_{2} \mathrm{O}(3: 1)$; $[\alpha] \mathrm{D}-63.9$ (c $\left.0.25, \mathrm{CH}_{3} \mathrm{OH}\right) ; \mathrm{IR}(\mathrm{NaCl}) v_{\max } 3435,2930$, $1660 \mathrm{~cm}^{-1} ;{ }^{1} \mathrm{H}$ and ${ }^{13} \mathrm{C}$ NMR spectra $\left(\mathrm{CDCl}_{3}\right)$ : Tables 1 and 2. EI-MS: $m / z 386[\mathrm{M}]^{+}, 354\left[\mathrm{M}-\mathrm{CH}_{3} \mathrm{OH}\right]^{+}$

Gomisin L1 (2): white powder; TLC $\left(\mathrm{SiO}_{2}\right) R f$ 0.57, $\mathrm{CHCl}_{3}$-EtOAc (10:1), (ODS) $R f \quad 0.50$, acetone $-\mathrm{H}_{2} \mathrm{O}$ (3:1); HPLC tR 22.10 min on YMC Pack ODS-AQ-HG $250 \times 20 \mathrm{~mm}$, ACN-H2O (42:58), Flow rate: $15 \mathrm{~mL} /$ min; $[\alpha] \mathrm{D}-59.6$ (c 0.10, $\left.\mathrm{CH}_{3} \mathrm{OH}\right)$; ECD $\left(\mathrm{CHCl}_{3}\right) 243(\Delta \varepsilon$ -1.93), IR ( NaCl) $v_{\max } 3400,2924,1614,1459 \mathrm{~cm}^{-1} ;{ }^{1} \mathrm{H}$ and ${ }^{13} \mathrm{C}$ NMR spectra $\left(\mathrm{CDCl}_{3}\right)$ : Tables 1 and 2; positive LR-ESI-MS: $m / z 387[\mathrm{M}+\mathrm{H}]^{+}, 409[\mathrm{M}+\mathrm{Na}]^{+}, 795$ $[2 \mathrm{M}+\mathrm{Na}]^{+}$; positive HR-ESI-MS: $m / z 387.1788[\mathrm{M}+$ $\mathrm{H}]^{+}$(calcd for $\mathrm{C}_{22} \mathrm{H}_{27} \mathrm{O}_{6}^{+}, 387.1802$ ).

Gomisin M1 (3): white powder; TLC $\left(\mathrm{SiO}_{2}\right)$ Rf 0.50, $\mathrm{CHCl}_{3}$-EtOAc (10:1), (ODS) Rf 0.47, acetone- $\mathrm{H}_{2} \mathrm{O}$ (3:1); HPLC $t_{\mathrm{R}} 23.70 \mathrm{~min}$ on YMC Pack ODS-AQ-HG $250 \times 20 \mathrm{~mm}$, ACN-H2O (42:58), Flow rate: $15 \mathrm{~mL} / \mathrm{min}$; [ $\alpha] \mathrm{D}-14.9$ (c 0.30, $\left.\mathrm{CH}_{3} \mathrm{OH}\right)$; IR ( $\left.\mathrm{NaCl}\right) v_{\max } 3447,2918$, $1614 \mathrm{~cm}^{-1} ;{ }^{1} \mathrm{H}$ and ${ }^{13} \mathrm{C}$ NMR spectra $\left(\mathrm{CDCl}_{3}\right)$ : Tables 1 and 2; EI-MS: $m / z 386[\mathrm{M}]^{+}, 370\left[\mathrm{M}-\mathrm{CH}_{4}\right]^{+}, 354[\mathrm{M}$ $\left.-\mathrm{CH}_{3} \mathrm{OH}\right]^{+}$.

Gomisin M2 (4): white powder; TLC $\left(\mathrm{SiO}_{2}\right)$ Rf 0.55, $\mathrm{CHCl}_{3}$-EtOAc (10:1), (ODS) $R f$ 0.35, acetone $-\mathrm{H}_{2} \mathrm{O}$ (3:1); $\alpha$ ]D 21.9 (c $\left.0.20, \mathrm{CH}_{3} \mathrm{OH}\right)$; IR ( $\left.\mathrm{NaCl}\right) v_{\max } 3321$, $2915,1651 \mathrm{~cm}^{-1} ;{ }^{1} \mathrm{H}$ and ${ }^{13} \mathrm{C}$ NMR spectra $\left(\mathrm{CDCl}_{3}\right)$ : Tables 1 and 2; EI-MS: $m / z 386[\mathrm{M}]^{+}, 370\left[\mathrm{M}-\mathrm{CH}_{4}\right]^{+}$, $354\left[\mathrm{M}-\mathrm{CH}_{3} \mathrm{OH}\right]^{+}$.

Gomisin M3 (5): white powder; TLC $\left(\mathrm{SiO}_{2}\right)$ Rf 0.45, $\mathrm{CHCl} 3-\mathrm{EtOAc}$ (10:1), (ODS) $R f$ 0.62, acetone- $\mathrm{H}_{2} \mathrm{O}$ (4:1); HPLC $t_{\mathrm{R}} 50.20$ min on YMC Pack ODS-AQ-HG $250 \times 20 \mathrm{~mm}, \mathrm{ACN}-\mathrm{H}_{2} \mathrm{O}(42: 58)$, Flow rate: $15 \mathrm{~mL} /$ min; $[\alpha]_{\mathrm{D}} 16.7\left(c \mathrm{c} 0.05, \mathrm{CH}_{3} \mathrm{OH}\right) ; \mathrm{ECD}\left(\mathrm{CHCl}_{3}\right) 225(\Delta \varepsilon$ -25.0), 254 ( $\Delta \varepsilon$ 12.3); IR ( $\mathrm{NaCl}) v_{\max } 3448,2922,1615$, $1460 \mathrm{~cm}^{-1} ;{ }^{1} \mathrm{H}$ and ${ }^{13} \mathrm{C}$ NMR spectra $\left(\mathrm{CDCl}_{3}\right)$ : Tables 1 and 2; positive LR-ESI-MS: $m / z 387[\mathrm{M}+\mathrm{H}]^{+}, 409[\mathrm{M}$

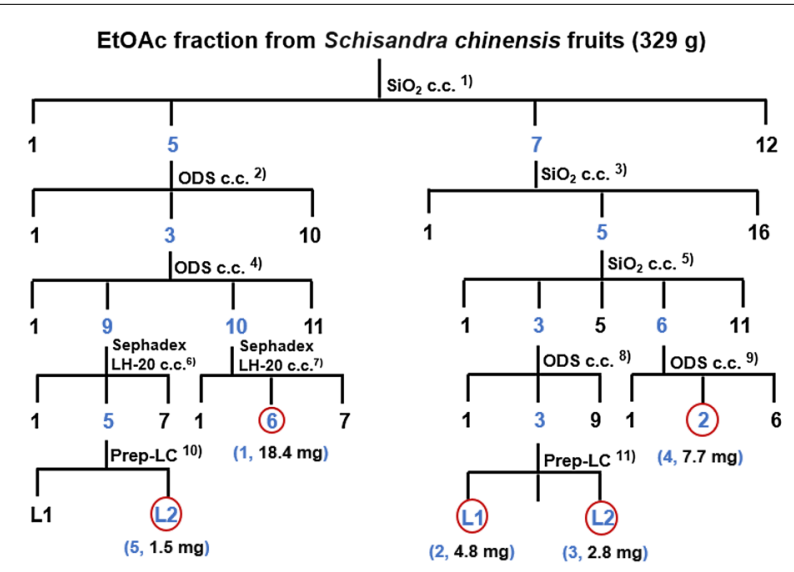

Fig. 1 Isolation of dibenzocyclooctadiene lignans from Schisandra chinensis fruits

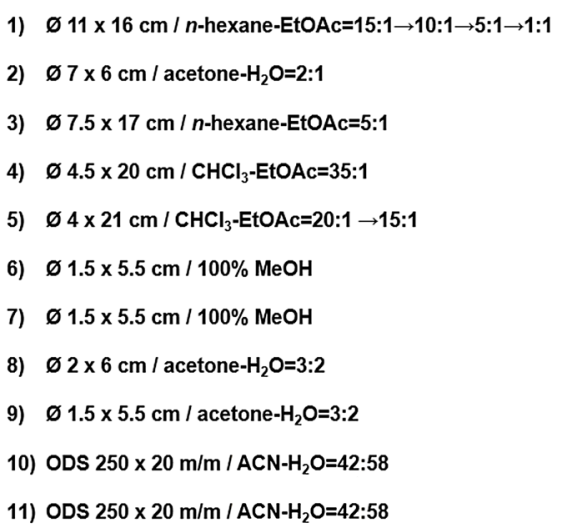

11) ODS $250 \times 20 \mathrm{~m} / \mathrm{m} / \mathrm{ACN}-\mathrm{H}_{2} \mathrm{O}=42: 58$ 
Table $1{ }^{1} \mathrm{H}$ NMR data of dibenzocyclooctadiene lignans from Schisandra chinensis fruits $\left(600 \mathrm{MHz}, \mathrm{CDCl}_{3}, \delta_{\mathrm{H}}\right.$, coupling pattern, $J$ in $\left.\mathrm{Hz}\right)$

\begin{tabular}{|c|c|c|c|c|c|}
\hline No of $\mathrm{H}$ & L2 (1) & L1 (2) & M1 (3) & M2 (4) & M3 (5) \\
\hline 4 & $6.47, \mathrm{~s}$ & $6.51, \mathrm{~s}$ & $6.51, \mathrm{~s}$ & $6.44, s$ & $6.48,5$ \\
\hline 6 & $\begin{array}{l}2.52, \mathrm{dd}, 13.8,7.2 \\
2.44, \mathrm{dd}, 13.8,1.2\end{array}$ & $\begin{array}{l}2.56, \mathrm{dd}, 13.8,7.2 \\
2.43, \mathrm{dd}, 13.8,1.2\end{array}$ & $\begin{array}{l}2.24, \mathrm{dd}, 13.2,9.6 \\
2.02, \mathrm{br} . \mathrm{d}, 13.2\end{array}$ & $\begin{array}{l}2.17, \mathrm{dd}, 13.2,10.2 \\
2.05, \text { br. } d, 13.2\end{array}$ & $\begin{array}{l}\text { 2.24, dd, } 13.2,9.6 \\
2.01, \text { br. d, } 13.2\end{array}$ \\
\hline 7 & $1.85, \mathrm{~m}$ & $1.89, \mathrm{~m}$ & $1.77, \mathrm{~m}$ & $1.86 \mathrm{~m}$ & $1.77, \mathrm{~m}$ \\
\hline 8 & $1.76, \mathrm{~m}$ & $1.80, \mathrm{~m}$ & $1.89, \mathrm{~m}$ & $1.92, \mathrm{~m}$ & $1.87, \mathrm{~m}$ \\
\hline 9 & $\begin{array}{l}2.22, \mathrm{dd}, 13.2,9.6 \\
2.00, \mathrm{br} . \mathrm{d}, 13.2\end{array}$ & $\begin{array}{l}2.30, \mathrm{dd}, 13.2,9.6 \\
2.03, \text { br. d, } 13.2\end{array}$ & $\begin{array}{l}2.57, \mathrm{dd}, 13.2,7.2 \\
2.52, \mathrm{br} . \mathrm{d}, 13.2\end{array}$ & $\begin{array}{l}2.58, \mathrm{dd}, 13.8,7.8 \\
2.47, \mathrm{dd}, 13.8,1.8\end{array}$ & $\begin{array}{l}2.53, \mathrm{dd}, 13.2,7.2 \\
2.46, \mathrm{dd}, 13.2,1.8\end{array}$ \\
\hline 11 & $6.61, s$ & $6.37, s$ & $6.37, s$ & 6.65 & $6.62, s$ \\
\hline 17 & $0.95, d, 7.2$ & $0.99, d, 7.2$ & $0.74, d, 7.2$ & $0.76, d, 7.2$ & $0.72, d, 6.6$ \\
\hline 18 & $0.70, d, 7.2$ & $0.73, d, 7.2$ & $0.97, d, 7.2$ & $0.98, d, 7.2$ & $0.96, d, 7.2$ \\
\hline 1-OMe & 3.76 & $3.87, \mathrm{~s}$ & $3.86, \mathrm{~s}$ & - & $3.77, \mathrm{~s}$ \\
\hline 12-OMe & 3.91 & $3.89, \mathrm{~s}$ & $3.88, \mathrm{~s}$ & 3.89 & - \\
\hline 13-OMe & - & $3.90, \mathrm{~s}$ & $3.91, \mathrm{~s}$ & 3.91 & $3.93, \mathrm{~s}$ \\
\hline 14-OMe & 3.49 & - & - & 3.57 & $3.51, \mathrm{~s}$ \\
\hline$-\mathrm{O}-\mathrm{CH}_{2}-\mathrm{O}-$ & $\begin{array}{l}5.94, d, 1.2 \\
5.90, d, 1.2\end{array}$ & $\begin{array}{l}5.97, d, 1.8 \\
5.93, d, 1.8\end{array}$ & $\begin{array}{l}5.95, \text { br. s } \\
5.92, \text { br. s }\end{array}$ & $\begin{array}{l}6.01, d, 1.8 \\
5.96, d, 1.8\end{array}$ & $\begin{array}{l}5.95, d, 1.2 \\
5.94, d, 1.2\end{array}$ \\
\hline
\end{tabular}

Table 2. ${ }^{13} \mathrm{C}$ NMR data of dibenzocyclooctadiene lignans from Schisandra chinensis fruits $\left(125 \mathrm{MHz}_{1} \mathrm{CDCl}_{3}, \delta_{\mathrm{C}}\right)$

\begin{tabular}{|c|c|c|c|c|c|}
\hline No & L2 (1) & L1 (2) & M1 (3) & M2 (4) & M3 (5) \\
\hline 1 & 141.40 & 141.31 & 141.13 & 137.00 & 141.23 \\
\hline 2 & 135.28 & 135.12 & 134.78 & 133.47 & $134.96^{*}$ \\
\hline 3 & 141.23 & 147.98 & 148.98 & 148.59 & 148.82 \\
\hline 4 & 106.34 & 106.66 & 103.59 & 102.30 & 103.35 \\
\hline 5 & 132.89 & 133.26 & 138.49 & 138.18 & 138.20 \\
\hline 6 & 39.11 & 39.08 & 35.76 & 35.75 & 35.66 \\
\hline 7 & 33.99 & 34.00 & 40.89 & 40.81 & 40.96 \\
\hline 8 & 40.97 & 40.94 & 33.65 & 33.45 & 29.89 \\
\hline 9 & 35.20 & 35.53 & 39.32 & 39.16 & 38.91 \\
\hline 10 & 140.46 & 140.11 & 134.64 & 135.85 & $135.00^{*}$ \\
\hline 11 & 110.41 & 104.02 & 107.70 & 112.50 & 113.42 \\
\hline 12 & 148.84 & 151.84 & 150.54 & 152.21 & 147.70 \\
\hline 13 & 137.55 & 133.26 & 133.61 & 140.52 & 137.83 \\
\hline 14 & 150.47 & 146.86 & 147.02 & 150.49 & 150.63 \\
\hline 15 & 121.62 & 115.85 & 116.76 & 118.69 & 122.64 \\
\hline 16 & 121.56 & 121.48 & 120.33 & 121.68 & 121.56 \\
\hline 17 & 22.05 & 22.15 & 13.03 & 12.89 & 12.84 \\
\hline 18 & 12.58 & 12.42 & 21.65 & 21.68 & 21.79 \\
\hline 1-OMe & 59.85 & 59.95 & 59.88 & - & 59.85 \\
\hline 12-OMe & - & 55.85 & 55.82 & 56.20 & - \\
\hline 13-OMe & 61.21 & 61.19 & 61.13 & 61.60 & 61.19 \\
\hline 14-OMe & 60.32 & - & - & 61.47 & 60.31 \\
\hline$-\mathrm{O}-\mathrm{CH}_{2}-\mathrm{O}-$ & 100.99 & 100.99 & 100.94 & 101.48 & 100.97 \\
\hline
\end{tabular}

* Position might be changed due to chemical shift overlapped

$+\mathrm{Na}]^{+}, 795\left[2 \mathrm{M}+\mathrm{Na}^{+}\right.$; positive HR-ESI-MS: $\mathrm{m} / z$ $387.1795[\mathrm{M}+\mathrm{H}]^{+}\left(\right.$calcd for $\left.\mathrm{C}_{22} \mathrm{H}_{27} \mathrm{O}_{6}{ }^{+}, 387.1802\right)$.

\section{Results and discussion}

Solvent extraction of Schisandra chinensis fruits, fractionation, and column chromatography for the EtOAc fraction with Sephadex LH-20, silica gel $\left(\mathrm{SiO}_{2}\right)$, and octadecyl $\mathrm{SiO}_{2}$ (ODS) as well as a preparative high performance liquid chromatography (prep-HPLC) yielded a new dibenzocyclooctadiene lignan and four previously reported analogues, which were identified to be gomisin L2 (1), gomisin L1 (2), gomisin M1 (3), and gomisin M2 (4) on the basis of MS, IR, and NMR data and comparison with the literature [17-20]. However, spectroscopic data and the procedure of structure determination for gomisin L1 (2) previously reported in literature [18] are incomplete and insufficiently described. Therefore, it will be of use for researchers to give complete data and reasonable description for structure determination.

Compound 2, a white powder, exhibited a molecular ion peak at $m / z 387.1788[\mathrm{M}+\mathrm{H}]^{+}$in the positive high resolution ESI-MS, establishing the molecular formula to be $\mathrm{C}_{22} \mathrm{H}_{26} \mathrm{O}_{6}$ (calcd for $\mathrm{C}_{22} \mathrm{H}_{27} \mathrm{O}_{6}{ }^{+}$, 387.1802). The IR bands at 3400 (hydroxy group), 1614, and $1459 \mathrm{~cm}^{-1}$ (aromatic moiety) and an orange-blue finding on TLC by spray of $10 \%$ sulfuric acid and heating suggested 2 as a dibenzocyclooctadiene lignan. The ${ }^{1} \mathrm{H}$ NMR spectrum (Table 1) displayed two singlet olefinic methine proton signals $\delta_{\mathrm{H}} 6.51,6.37$ due to two aromatic protons in a biphenyl moiety. As shown by the signals of $\mathrm{H}-4$ and $\mathrm{H}-11$ at different chemical shifts, the biphenyl unit had an asymmetric plane. At the oxygenated field, one dioxygenated methylene proton signal showed germinal coupling at $\delta_{\mathrm{H}} 5.97(\mathrm{~d}, J=1.8 \mathrm{~Hz}$; coupling pattern, 
coupling constant in $\mathrm{Hz}$ ) and $5.93(\mathrm{~d}, 1.8)$, and three methoxy proton signals at $\delta_{\mathrm{H}} 3.90,3.89$, and 3.87 were observed. At high magnetic field, the following proton signals were identified: two methines at $1.89(\mathrm{~m})$ and $1.80(\mathrm{~m})$; two methylenes with germinal coupling at $\delta_{\mathrm{H}}$ $2.56(\mathrm{dd}, 13.8,7.2)$ and $2.43(\mathrm{dd}, 13.8,1.2)$; at $\delta_{\mathrm{H}} 2.30(\mathrm{dd}$, 13.2, 9.6) and 2.03 (br. d, 13.2); and two doublet methyls at $\delta_{\mathrm{H}} 0.99(\mathrm{~d}, 7.2)$ and $0.73(\mathrm{~d}, 7.2)$. The proton NMR signals of OMe-1 and -14 usually appears at more upfield than those of OMe-2, $-3,-12$, and -13 owing to a shielding influence by the neighboring phenyl moieties. The former compounds having OMe group at $\mathrm{C}-1$ and -14 usually show the chemical shift of the methoxy group at ca. $\delta_{\mathrm{H}} 3.55$, while the latter compounds having $\mathrm{OMe}$ group at $\mathrm{C}-1,-3,-12$, and -13 at ca. $\delta_{\mathrm{H}} 3.90$ [21]. Besides, the proton NMR signals of OMe-1 and -14 are a little shifted to downfield in case of having a dioxymethylene moiety at the next position [9]. Therefore, OMe-1 proton signal was observed at $\delta_{\mathrm{H}} 3.87$. The other two methoxy groups of compound 2 were observed at $\delta_{\mathrm{H}} 3.90$ and 3.89 , suggesting that $\mathrm{C}-14$ had a free hydroxyl group. In the ${ }^{13} \mathrm{C}$ NMR spectrum (Table 2), 22 carbon signals were detected including one deoxygenated methylene $\left(\delta_{\mathrm{C}} 100.99\right)$ and three methoxy $\left(\delta_{\mathrm{C}} 61.19,59.95,55.85\right)$ signals, confirming compound 2 to be a lignan. The carbon signals of the biphenyl moiety were composed of six oxygenated olefinic quaternary carbons $\left(\delta_{\mathrm{C}} 151.84\right.$, $147.98,146.86,141.31,135.12,133.26)$, four olefinic quaternary carbons $\left(\delta_{C} 140.11,133.26,121.48,115.85\right)$, and two olefinic methines $\left(\delta_{\mathrm{C}} 106.66,104.02\right)$. At high magnetic field, the ${ }^{13} \mathrm{C}$ NMR spectrum showed two methines $\left(\delta_{\mathrm{C}} 40.94,34.00\right)$, two methylenes $\left(\delta_{\mathrm{C}} 39.08,35.53\right)$, and two methyls $\left(\delta_{\mathrm{C}} 22.15,12.42\right)$. The chemical shifts of two methyl carbons appeared over a narrow range $\left(\delta_{\mathrm{C}}\right.$ 12.42 and 22.15), the upfield signal was assigned to be an axial methyl carbon (C-18), and the downfield one to an equatorial methyl carbon (C-17) [22]. Therefore, compound 2 had a cis-dimethyl moiety was a cyclooctadiene ring [23]. The abovementioned NMR suggested 2 to be a dibenzocyclooctadiene lignan with three methoxy, one hydroxy, and one dioxymethylene group in the biphenyl moiety. The protection of a hydroxyl group by methyl moiety led to 3-4 ppm downfield shifting of phenyl carbon [21]. Because the oxygenated olefinic quaternary carbons $\mathrm{C}-12$ and $\mathrm{C}-14$ were observed at $\delta_{\mathrm{C}} 151.84$ and 146.86 , respectively, C-14 was suggested to have a hydroxyl group. The methoxy carbons next to the biphenyl bond (C-3 and $\mathrm{C}-12)$ are upfield shifted by $5 \mathrm{ppm}$ (around $\delta_{\mathrm{C}} 55$ ) in contrast to those of others $\left(\mathrm{C}-1, \mathrm{C}-2, \mathrm{C}-3\right.$, and $\mathrm{C}-14$; about $\left.\delta_{\mathrm{C}} 60\right)$ [21]. The three methoxy carbons were detected at $\delta_{\mathrm{C}} 61.19,59.96$, and 55.85 , suggesting that $\mathrm{C}-12$ has a methoxy group. The chemical shifts of $\mathrm{C}-1$ and $\mathrm{C}-14$ were $\delta_{\mathrm{C}} 141.31$ and 146.86 , respectively. The neighboring carbon $(\mathrm{C}-1)$ from the dioxymethylene group is observed more upfield than other carbons, such as $\mathrm{C}-14$, indicating the dioxymethylene group at $\mathrm{C}-2$ and $\mathrm{C}-3$ [22]. Additionally, two oxygenated olefin quaternary carbon signals $\left(\delta_{\mathrm{C}} 135.12, \mathrm{C}-2\right.$; $147.98, \mathrm{C}-3)$ showed correlations with dioxymethylene proton $\delta_{\mathrm{H}} 5.97$ and 5.93 signals and an olefin methine proton $\delta_{\mathrm{H}} 6.51(\mathrm{H}-4)$ signal in the HMBC spectrum, confirming the position of the dioxymethylene group. These findings established the planar structure of compound 2 (Fig. 2). The absolute configuration of the biphenyl chromophore can be discerned based on the characteristic CD spectra. The $S$ configuration derivatives show a $(+)$-Cotton effect at $210 \mathrm{~nm}$ and a (-)-Cotton effect at $240 \mathrm{~nm}$ in CD. Conversely, the $R$ configuration derivatives yield a $C D$ spectrum with a (-)-Cotton effect at $210 \mathrm{~nm}$ and a (+)-Cotton effect at $240 \mathrm{~nm}$ [23]. The CD spectrum of 2 gave a negative Cotton effect at $243 \mathrm{~nm}$, proposing 2 to have an $S$ configuration in biphenyl structure [24]. In addition, proton signals of $\mathrm{H}-8\left(\delta_{\mathrm{H}} 1.80\right)$ and $\mathrm{H}-18\left(\delta_{\mathrm{H}} 0.73\right)$ were upfield-shifted confirming 2 to possess an $S$ configuration because an axial methyl group (H-18) or hydrogen (H-8) is shielded by the biphenyl moiety, leading to an upfield effect [20]. Based on these findings, the chemical structure of $\mathbf{2}$ was identified as (aS)-(6S,7R)-2,3,13-trimethoxy-6,7-dimethyl-5,6,7,8-tetrahydrobenzo[3',']cycloocta[1,2':4,5]benzo[1,2-d][1,3] dioxol-1-ol, gomisin L1.

Compound 5, a white powder, displayed a molecular ion peak $m / z 387.1795[\mathrm{M}+\mathrm{H}]^{+}$in the positive highresolution ESI-MS, establishing the molecular formula to be $\mathrm{C}_{22} \mathrm{H}_{26} \mathrm{O}_{6}$ (calcd for $\mathrm{C}_{22} \mathrm{H}_{27} \mathrm{O}_{6}{ }^{+}, 387.1802$ ). The IR bands at 3348 (hydroxy group), 1615, and $1460 \mathrm{~cm}^{-1}$ (aromatic moiety) and the orange-blue color finding on TLC by spray of $10 \%$ sulfuric acid and heating suggested 5 as a dibenzocyclooctadiene lignan. ${ }^{1} \mathrm{H}$ and ${ }^{13} \mathrm{C}$ NMR spectra proposed $\mathbf{5}$ to be a dibenzocyclooctadiene lignan with three methoxy, one hydroxy, and one dioxymethylene moieties in the biphenyl ring. The ${ }^{1} \mathrm{H}$ NMR chemical shifts at $\delta_{\mathrm{H}} 3.93$ (13-OMe), 3.77 (1-OMe), and 3.51 (14-OMe), as well the ${ }^{13} \mathrm{C}$ NMR chemical shifts at 61.19 (13-OMe), 60.31 (14-OMe), and 59.85 (1-OMe) of three methoxy moieties suggested a hydroxyl moiety at C-12. Additionally, two oxygenated olefin quaternary carbons $\left(\delta_{\mathrm{C}} 134.96, \mathrm{C}-2 ; 148.82, \mathrm{C}-3\right)$ showed correlation with dioxymethylene proton $\left(\delta_{\mathrm{H}} 5.95,5.94\right)$ signals and with an olefin methine proton $\left(\delta_{\mathrm{H}} 6.48, \mathrm{H}-4\right)$ signal in the HMBC spectrum, confirming the dioxymethylene moiety to be at $\mathrm{C}-2$ and $\mathrm{C}-3$. The $\mathrm{CD}$ spectrum of 5 exhibited a negative Cotton effect at $225 \mathrm{~nm}$ and a positive Cotton effect at $254 \mathrm{~nm}$, proposing 5 to have an $R$ 


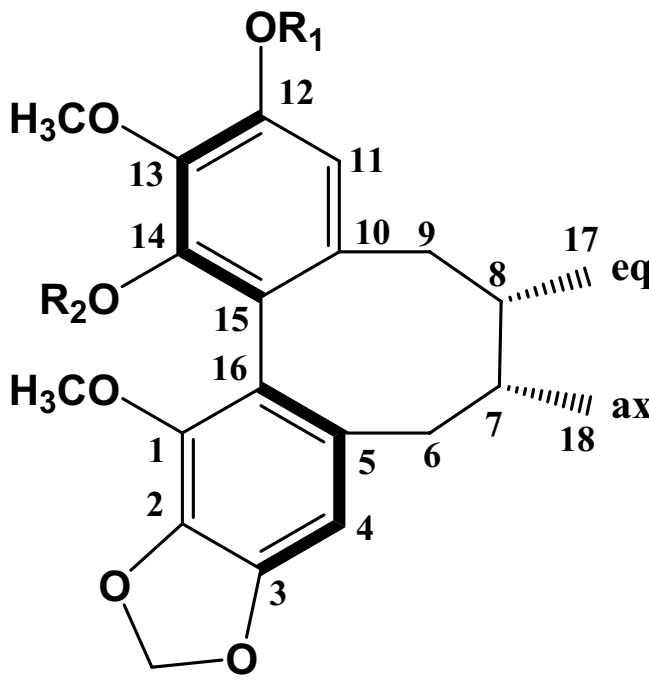

gomisin L2 (1): $\mathrm{R}_{\mathbf{1}}=\mathrm{H}, \mathrm{R}_{\mathbf{2}}=\mathrm{CH}_{3}$

gomisin L1 (2): $\mathrm{R}_{1}=\mathrm{CH}_{3}, \mathrm{R}_{2}=\mathrm{H}$

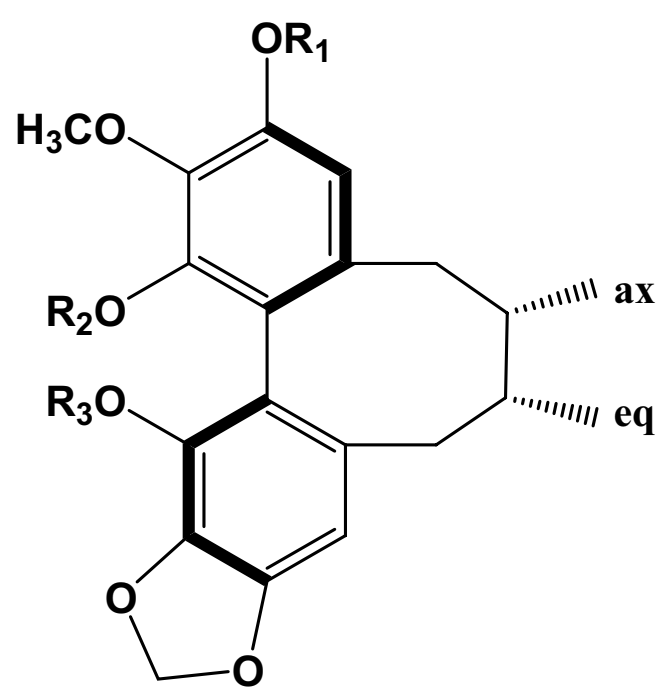

gomisin $M 1$ (3): $\mathbf{R}_{1}, \mathrm{R}_{3}=\mathrm{CH}_{3}, \mathrm{R}_{2}=\mathrm{H}$

gomisin M2 (4): $\mathrm{R}_{1}, \mathrm{R}_{2}=\mathrm{CH}_{3}, \mathrm{R}_{3}=\mathrm{H}$

gomisin M3 (5): $\mathrm{R}_{\mathbf{1}}=\mathrm{H}, \mathrm{R}_{\mathbf{2}}, \mathrm{R}_{\mathbf{3}}=\mathrm{CH}_{\mathbf{3}}$

Fig. 2 Chemical structures of dibenzocyclooctadiene lignans from Schisandra chinensis fruits

configuration in biphenyl ring structure [17, 18, 24-27]. Taken Additional file 1 together, the chemical structure of 5 was identified as $(\mathrm{a} R)-(6 S, 7 R)-1,2,13$-trimethoxy6,7-dimethyl-5,6,7,8-tetrahydrobenzo[3',4']cycloocta $[1,2$ ':4,5]benzo[1,2-d][1,3]dioxol-3-ol, named gomisin M3.

In the present study, a new dibenzocyclooctadiene lignan (name as gomisin M3) along with four known ones, gomisin L2, L1, M1, and M2, were isolated through repeated column chromatography using silica gel, octadecyl silica gel, and Sephadex LH-20 resins from the EtOAc fraction of Schisandra chinensis fruits. Their chemical structures including stereostructure for axial chirality were determined without ambiguity based on the analysis of NMR, IR, MS, and CD data.

\section{Additional information}

Additional information $\left({ }^{1} \mathrm{H}\right.$ and ${ }^{13} \mathrm{C}$ NMR spectra of dibenzocyclooctadiene lignans 1-5 accompanies this paper at https://doi.org/ (Additional file 1: Figures S1-S5).

\section{Supplementary Information}

The online version contains supplementary material available at https://doi. org/10.1186/s13765-021-00618-1.

Additional file 1: Figure S1. 1H- and 13C-NMR spectra of gomisin L2 (1) (600/150 MHz, CD3OD). Figure S2. 1H- and 13C-NMR spectra of gomisin L1 (2) $(600 / 150 \mathrm{MHz}, \mathrm{CDCl} 3)$. Figure S3. $1 \mathrm{H}$ - and 13C-NMR spectra of gomisin M1 (3) $(600 / 150 \mathrm{MHz}, \mathrm{CDCl} 3)$. Figure S4. $1 \mathrm{H}$ - and 13C-NMR spectra of gomisin M2 (4) $(600 / 150 \mathrm{MHz}, \mathrm{CDCl} 3)$. Figure S5. $1 \mathrm{H}$ - and 13C-NMR spectra of gomisin M3 (5) $(600 / 150 \mathrm{MHz}, \mathrm{CDCl})$.

\section{Acknowledgements}

This work was supported by the "Cooperative Research Program for Agriculture Science \& Technology Development" (Project no. PJ01420403), Rural Development Administration, Republic of Korea.

\section{Authors' contributions}

TN N, Y-G L, and N-I B planned the study and wrote the paper. TN N, Y-G L, $H-G K, D H Y$, and DY L isolated lignans. TN N, Y-G L, and N-I B determined the chemical structure of lignans. JT J collected the fruits of Schisandra chinensis and identified. All authors read and approved the final manuscript.

Funding

RDA (Project no. PJ01420403) funded this study.

Availability of data and materials

The data and materials used in this study are available under permission from the corresponding author on reasonable request. 


\section{Declarations}

Competing interests

There are no conflicts to declare.

\section{Author details}

${ }^{1}$ Graduate School of Biotechnology, Kyung Hee University, Yongin 17104, Republic of Korea. ${ }^{2}$ Department of Herbal Crop Research, National Institute of Horticultural and Herbal Science, RDA, Eumseong 27709, Republic of Korea.

Received: 12 March 2021 Accepted: 28 May 2021

Published online: 04 June 2021

\section{References}

1. Flora of China Editorial Committee (1996) Flora of China. Science Press, Beijing, p 252

2. Chinese Pharmacopoeia Commission (2005) Pharmacopoeia of the People's Republic of China, People's Medical Publishing House, Beijing, p 109

3. Richardson MD, Peterson JR, Clark AM (1992) Bioactivity screenings of plants selected on the basis of folkloric use or presence of lignans in a family. Phytotherapy Res 6:274-278

4. Han HJ, Jung UJ, Kim HJ, Moon BS, Cho SJ, Park YB, Lee DG, Choi MS (2015) Dual effects of a mixture of grape pomace (Campbell Early) and Omija fruit ethanol extracts on lipid metabolism and the antioxidant defense system in diet-induced obese mice. Nutr Res Pract 9:227-234

5. Liu KT, Lesca P (1982) Pharmacological properties of dibenzo[a, c] cyclooctene derivatives isolated from Fructus Schizandrae chinensis III. Inhibitory effects on carbon tetrachloride-induced lipid peroxidation, metabolism and covalent binding of carbon tetrachloride to lipids. Chem Biol Interact 41:39-47

6. Nishiyama N, Chu PJ, Saito H (1996) An herbal prescription, S-113m, consisting of biota, ginseng and schizandra, improves learning performance in senescence accelerated mouse. Biol Pharm Bull 19:388-393

7. Kim HS, Lee JH, Park HS, Lee GS, Kim HW, Ha KT, Kim BJ (2015) Schizandra chinensis extracts induce apoptosis in human gastric cancer cells via JNK p38 MAPK activation and the ROS-mediated/mitochondria-dependent pathway. Pharm Biol 53:212-219

8. Kim MG, Lee CH, Lee HS (2010) Anti-platelet aggregation activity of lignans isolated from Schisandra chinensis fruits. J Kor Soc Appl Biol Chem 53:740-745

9. Opletal L, Sovova H, Bartlova M (2004) Dibenzo[a, c]cyclooctadiene lignans of the genus Schisandra: importance, isolation and determination. J Chromatogr 812:357-371

10. Hancke JL, Burgos RA, Ahumada F (1999) Schisandra chinensis (Turcz.) Baill. Fitoterapia 70:451-471

11. Song W, Tong Y (1983) The occurrence of some important lignans in Wu Wei Zi (Schisandra chinensis) and its allied species. Acta Pharm Sin 18:138-143

12. Tang W, Eisenbrand G (1992) Chinese drugs of plant origin. Chemistry, pharmacology, and use in traditional and modern medicine. Springer, Berlin, p 903
13. Ren R, Ci XX, Li HZ, Luo GJ, Li RT, Deng XM (2010) New dibenzocyclooctadiene lignans from Schisandra sphenanthera and their proinflammatory cytokine inhibitory activities. Z Für Nat B 65:211-218

14. McConathy J, Owens MJ (2003) Stereochemistry in drug action. Prim Care Companion J Clin Psychiatry 5:70-73

15. Chiu PY, Leung HY, Poon MKT, Mak DHF, Ko KM (2006) Effects of schisandrin B enantiomers on cellular glutathione and menadione toxicity in AML12 hepatocytes. Pharmacol 77:63-70

16. Seo KH, Nam YH, Lee DY, Ahn EM, Kang TH, Baek NI (2015) Recovery effect of phenylpropanoid glycosides from Magnolia obovata fruit on alloxaninduced pancreatic islet damage in zebrafish (Danio rerio). Carbohydr Res 416:70-74

17. Nakajima K, Taquchi H, Ikeya Y, Endo T, Yosioka I (1983) Constituents of Schizandra chinensis Baill. XIII. Quantitative analysis of lignans in the fruits of Shcizandra chinensis Baill. By high performance liquid chromatography. Yakuqaku Zasshi 103:743-749

18. Ikeya Y, Taguchi H, Yosioka I (1982) The constituents of schizandra chinensis BAILL. $X$. The structures of $\gamma$-schizandrin and four new lignans, $(-)$-gomisins $\mathrm{L} 1$ and $\mathrm{L} 2,( \pm)$-gomisin $\mathrm{M} 1$ and $(+)$-gomisin M2. Chem Pharm Bull 30:132-139

19. Chen M, Xu X, Xue B, Yabg P, Liao Z, Morris-Natschke SL, Lee KH, Chen D (2013) Neglschisandrins E-F: two new lignans and related cytotoxic lignans from Schisandra neglecta. Molecules 18:2297-2306

20. Li LN, Chen Y (1986) Further dibenzo cyclooctadiene lignans from roots and stems of kadsura longipedunculata. Planta Med 52:410-411

21. Chang J, Reiner J, Xie J (2005) Progress on the chemistry of dibenzocyclooctadiene lignans. Chem Rev 105:4581-4609

22. Ikeya Y, Taguchi H, Sasaki H, Nakajima K, Yosioka I (1980) The constituents of Schizandra chinensis BAILL. VI. ${ }^{13} \mathrm{C}$ Nuclear magnetic resonance spectroscopy of dibenzocyclooctadiene lignans. Chem Pharm Bull 28:2414-2421

23. Ikeya Y, Taguchi H, Yosioka I (1980) The constituents of Schizandra chinensis BAILL. VII. The structures of three new lignans, (-)-gomisin $\mathrm{K}_{1}$ and (+)-gomisins $K_{2}$ and $K_{3}$. Chem Pharm Bull 28:2422-2427

24. Li HM, Luo YM, Pu JX, Li XN, Lei C, Wang RR, Zheng YT, Sun HD, Li RT (2008) Four new dibenzocyclooctadiene lignans from Schisandra rubriflora. Helv Chim Acta 91:1053-1062

25. Blunder M, Pferschy-Wenzig EM, Fabian WMF, Hufner A, Kunert O, Saf R, Schuhly W, Bauer R (2010) Derivatives of schisandrin with increased inhibitory potential on prostaglandin $\mathrm{E}_{2}$ and leukotriene $\mathrm{B}_{4}$ formation in vitro. Bioorg Med Chem 18:2809-2815

26. Chen DF, Xu GJ, Yang XW, Hattori M, Tezuka Y, Kikuchi T, Namba T (1992) Dibenzocyclo-octadiene lignans from Kadsura heteroclite. Phytochemistry 31:629-632

27. Tan R, Li LN, Feng QC (1984) Studies on the chemical constituents of Kadsura longipedunculata: Isolation and structure elucidation of five new lignans. Planta Med 50:414-417

\section{Publisher's Note}

Springer Nature remains neutral with regard to jurisdictional claims in published maps and institutional affiliations.

\section{Submit your manuscript to a SpringerOpen ${ }^{\circ}$ journal and benefit from:}

- Convenient online submission

Rigorous peer review

- Open access: articles freely available online

- High visibility within the field

Retaining the copyright to your article

Submit your next manuscript at springeropen.com 